\title{
CORPORATE GOVERNANCE, LIQUIDITY AND MATURITY ANALYSIS ON BONDS YIELD WITH BOND RATINGS AS INTERVENING VARIABLES IN COMPANIES LISTED ON IDX
}

\author{
Alinto Alvin*, Isnurhadi, Widiyanti Marlina \\ Faculty of Economics, University of Sriwijaya, Palembang, Indonesia \\ *E-mail: alalvin4@gmail.com
}

\begin{abstract}
The study aims to examine how corporate governance, liquidity and maturity affect bonds yield with intervening variable such as bond ratings. The data using secondary data which is annual data from companies whose bonds are outstanding during the 2016-2018 period. The sampling technique using purposive sampling method and the sample consists of 285 corporate bonds. The analysis technique using path analysis and the data was processed using the AMOS Structural Equation Modeling (SEM) program. The results showed that there is no effect of corporate governance on bonds yield, while the effect of corporate governance on bond ratings is positive. For liqudity, there is no effect of liquidity on bonds yield, while the effect of liquidity on bond ratings is significant negative. For maturity, the effect of maturity on bonds yield is significant positive and also there is positive effect of maturity on bond ratings. The effect of bond ratings on bonds yield is significant negative. These results indicate that the ratings in this study can mediate corporate governance, liquidity and maturity variables on bond yields. The result also showing that bond ratings fully mediate the effect of corporate governance and liquidity on bonds yield while for maturity, bond rating partially mediated the effect of maturity on bonds yield.
\end{abstract}

\section{KEY WORDS}

Corporate Governance, liquidity, maturity, bond ratings, bonds yield.

Bonds which are a form of investment that are well known to the general public according to the Indonesia Stock Exchange, are long-term securities that can be traded in which there is an agreement between the parties issuing the bonds to pay compensation in the form of interest and pay off the principal debt obligations at the agreed time by bond buyers. Bonds themselves are quite attractive to many investors because the risks of bonds are not that much (Brigham \& Houston, 2016), and usually bonds have guarantees so that if the worst thing happens, such as a company going bankrupt then the guarantee can be used to pay investors who have previously invested in the company.

The following is the annual data on corporate bond transactions that occurred in Indonesia from 2016 to 2018 :

Table 1 - Corporate Bond Transaction Data for 2016-2018

\begin{tabular}{|c|c|c|}
\hline Year & Outstanding (Trillion Rupiah) & Volume (Trillion Rupiah) \\
\hline 2016 & 311,679 & 224,318 \\
\hline 2017 & 387,969 & 325,133 \\
\hline 2018 & 411,857 & 327,617 \\
\hline
\end{tabular}

Source: Indonesia Stock Exchange (2020).

The data above shows an increase in outstanding and trading volume of bonds from year to year. This shows that the bond market in Indonesia continues to grow every year. It can be said that bonds are an investment that is no less attractive than stocks that are better known to the public.

In the transaction, the investor will certainly not be separated from the desire to obtain high returns. This return in bonds we usually call the bonds yield. Yield is one thing that is interesting when viewed from the explanation above, where the increase in transaction 
volume is followed by an increase in the yield index of the corporate bonds. It can be said that the better or greater the yield value can encourage investors to invest in bonds or it can be said vice versa, the more companies that offer bonds which of course will offer better or higher yields to attract investors to invest in their bonds. So what are the factors that can affect the yield, because the investor certainly wants a high yield from the investment they chooses.

Research conducted by Isnurhadi \& Yanti (2009), Han (2016), states that corporate governance affects bonds yield. Bhojraj \& Sengupta (2003) say that companies with strong corporate governance will produce low yields. Meanwhile, Bradley et al. (2011) in their research results show that corporate governance which consists of several attributes has a positive and negative influence on yield depending on these attributes.

In terms of liquidity, Hamida et al. (2017) stated that liquidity does not have a significant effect on bond yields. Research conducted by Simu (2017), Susanti \& Permana (2017), Hamid et al. (2019), Putri et al. (2020), state that yields are not influenced by liquidity, this result is certainly contrary to what is stated by Ross \& Westerfield (2012) and Brigham \& Ehrhardt (2017) which states that liquidity can affect yields.

Research of Aisah \& Haryanto (2012), Che-Yahya et al. (2016), Putri et al. (2020) found that maturity has an influence on bond yields. Simu (2017) add that the effect of maturity on yield is a positive influence. Contrary to the results of Simu (2017) research, Susanti \& Permana (2017) study found that the effect of maturity on yield was negative. Meanwhile, the results of research by Laeli \& Faizah (2019) stated that there was no effect of maturity on bond yields.

Then, the results of research belonging to Isnurhadi \& Yanti (2009), Aisah \& Haryanto (2012), Chung et al. (2019), Dewi \& Utami (2020) stated that bond ratings affect bond yields. According to Surya \& Nasher (2011), Hendaryadi et al. (2012), Simu (2017), Susanti \& Permana (2017), Weniasti \& Marsoem (2019), Putri et al. (2020) there is an opposite relationship between bond ratings and corporate bond yields. Meanwhile, according to Hamid et al. (2019) there is no effect of rating on yield.

In terms of bond ratings, according to Brigham \& Houston (2016), bond ratings are determined based on various factors, namely quantitative factors and qualitative factors. Quantitative factors can be in the form of financial ratios. While the qualitative factors can be in the form of bond contract provisions such as coupon rates, maturity etc. It also includes the company's competitive capabilities, company management capabilities, etc.

Previous research, such as that conducted by Setyaningrum (2005), Ashbaugh-Skaife et al. (2006), Bradley et al. (2011), Altin et al. (2016), Partiningsih (2016), Han (2016), Tarigan \& Fitriany (2018), Sahabuddin \& Hadianto (2020) state that corporate governance affects bond ratings. Bhojraj \& Sengupta (2003), Kim \& Kim (2014), Elhaj et al. (2015), Altin et al. (2016) also show the results of research which states that companies with strong corporate governance have a high probability of getting a better rating. Meanwhile, contrary to the results, the research of de Souza Murcia et al. (2014), Sari \& Henny (2015), Utomo et al. (2016) stated that corporate governance does not affect bond ratings.

Research conducted by Mardiyati et al. (2015) shows that liquidity has a positive but not significant effect on bond ratings. Then there is Partiningsih (2016), Hamid et al. (2019) which shows that liquidity has a significant positive effect on bond ratings. While the results of research conducted by de Souza Murcia et al. (2014), Rizal \& Sutanti (2015), Veronica (2015), Partiningsih (2016), Blesia \& Pramudika (2016), Sari et al. (2018), Dewi \& Utami (2020) show that liquidity has no effect on bond ratings.

Then, research conducted by Veronica (2015), Laeli \& Faizah (2019) stated that maturity has a significant effect on bond ratings. Meanwhile, the results of research conducted by Ikhsan et al. (2012), Blesia \& Pramudika (2016) found that maturity does not affect bond ratings. Based on the explanation mentioned above the study aim to examine the effect of corporate governance, liquidity and maturity on bonds yield with bond ratings as the mediating variable. 


\section{LITERATURE REVIEW}

Bonds are long-term contracts in which the borrower or bond issuer agrees to make payments of interest and principal on a certain date to the bondholder or investor (Brigham \& Houston, 2016). One of a characteristic of bonds is maturity. According to Otoritas Jasa Keuangan (OJK) (2020), maturity or the age of the bond is the date on which bondholders will receive repayment of the principal or nominal value of the bonds they own. The maturity period of the bonds varies from 365 days or one year to more than 5 years. According to Choudhry et al. (2009), the yield value will continue to decline the longer the maturity of a bond has. According to Ross \& Westerfield (2012), maturity is one of the components needed in determining bond yields. The yield components include bond prices, coupon rates and maturity. Then, Baker \& Filbeck (2013) also stated that investments with high yields and longer maturities tend to decline faster than investments with small yields and shorter maturities. Maturity in this study is measured with years.

Corporate governance can be defined as a set of laws, rules, and procedures that affect a company's operations and the decisions made by its managers (Brigham \& Ehrhardt, 2017). In addition to regulations, corporate governance is under the control of the company, there are also environmental factors beyond the control of the company, such as regulations, block ownership patterns, competition in the product market, media, and litigation. Large boards of directors (which have more than 10 members) are often less effective than smaller boards (Brigham \& Ehrhardt, 2017). As anyone who has ever been on a committee can attest, individual participation tends to decrease as committee size increases. Thus, there is a greater likelihood that large board members will be less active than smaller board members.In practice, companies can make calls from the bonds they sell. According to (Brigham \& Houston, 2016), if we buy a callable bond and the company calls the bond, then we will not have the option to hold it until maturity. Therefore, we will not get yield to maturity. The proxy for this variable is the board size. Board size is measured by how many board members there are in the company.

According to Brigham \& Ehrhardt (2017), financial ratios are designed to retrieve important information that is not seen directly from assessing the company's financial statements. The financial ratio referred to in this study is the liquidity ratio. According to Ross \& Westerfield (2012), companies with low liquidity tend to choose to provide higher yields. Brigham \& Ehrhardt (2017) stated that investors that investing in bonds want bond yields from companies that have good liquidity. Low liquidity can result in high yields. The liquidity ratio is usually used to measure the company's ability to meet its short-term obligations. The liquidity ratio in this study will be proxied by the current ratio, which can be measured using the following formula (Brigham \& Houston, 2016):

$$
\text { Current Ratio }=\frac{\text { Current Assets }}{\text { Current Liabilities }}
$$

Bond rating is a risk scale of all bonds traded so as to indicate the level of safety of a bond investment for investors. The level of safety in investing can be shown from the company's ability to pay interest and repay the loan principal. For this reason, in determining the bond rating scale, it is necessary to determine the variables that affect the bonds and then calculate them. From these calculations, a standard is found to get a certain rating (Brigham \& Houston, 2016). According to Ross \& Westerfield (2012), bonds with a lower rating are more likely to have a higher yield than bonds with a higher rating.Bond ratings in this study using ratings from PT. Pefindo (PT. Pemeringkat Efek Indonesia). Bond ratings are measured by scoring. The lowest to the highest rank will be given a score of 1 to 18 starting from lowest rating $D$ to $A A A$.

According to Tandelilin (2010), bond yields can be in the form of the rate of return that investors will receive if they buy bonds at the current market price and hold the bonds until maturity. Yield of bonds will be measured by calculation using Yield to Maturity. 


$$
\text { Yield to Maturity }=\frac{C_{i}+\frac{P_{p}-P}{n}}{\frac{P_{p}+P}{2}}
$$

Where: $\mathrm{P}=$ Current bond price; $\mathrm{N}=$ Number of years to maturity; $\mathrm{C}_{\mathrm{i}}=$ Bond coupon payments every year; $P_{p}=$ face value of bonds.

\section{METHODS OF RESEARCH}

The study used data from the annual data of corporate bonds listed on the IDX during the 2016-2018 period. The sampling method used is a purposive sampling method with limited data on conventional corporate bonds recorded during the study period and does not include Islamic bonds or sukuk. The sample consists of 285 corporate bonds. The analytical technique used is path analysis and the data processed by using the AMOS SEM program.

\section{RESULTS OF STUDY}

The following are the results of the study obtained from the output of the AMOS SEM program. The following table shows the significance test result:

Table 2 - Significance Test Result

\begin{tabular}{|l|l|l|}
\hline $\mathrm{n} / \mathrm{n}$ & Path Coefficient & $\mathrm{P}$ \\
\hline rating <--- corporate governance & 0.3773 & ${ }^{\star * *}$ \\
\hline rating <--- liquidity & -0.2839 & $* *$ \\
\hline rating <--- maturity & 0.1119 & 0.0487 \\
\hline yield <--- corporate governance & -0.0285 & 0.6741 \\
\hline yield <--- liquidity & -0.1180 & 0.0699 \\
\hline yield <--- maturity & 0.4947 & $* \star *$ \\
\hline yield <--- rating & -0.6559 & ${ }^{* * *}$ \\
\hline
\end{tabular}

Source: Result of output from SEM AMOS (2020).

The symbol of ${ }^{* * *}$ on the table above mean $P$ value $<0.05$.

The effect of corporate governance on bond ratings shows a very small $p$ value, which is less than 0.05 and the path coefficient of 0.2112 . $P$ value is smaller than 0.05 and the path coefficient is 0.2112 , so there is a significant positive effect of corporate governance on bond ratings. According to Brigham \& Houston (2016), the management ability of a company is one of the factors that can affect bond ratings. Then according to Choudhry et al. (2009), bond ratings often reflect the financial health of a company and its management. This means that the better the corporate governance, the better the ranking that can be obtained by the company. The results of this study show the same results as previous studies conducted by Setyaningrum (2005), Ashbaugh-Skaife et al. (2006), Bradley et al. (2011), Altin et al. (2016), Partiningsih (2016), Han (2016), Tarigan \& Fitriany (2018), Sahabuddin \& Hadianto (2020) which state that corporate governance affects bond ratings. The results of research Bhojraj \& Sengupta (2003), Kim \& Kim (2014), Elhaj et al. (2015), Altin et al. (2016) also show the same results which state that companies with strong corporate governance have a high probability of getting a better rating.

The effect of liquidity on bond ratings shows that the $p$ value is very small, which is less than 0.05 and the path coefficient is -0.2629 . Because the $p$ value is smaller than 0.05 and the path coefficient is -0.2629 , there is a significant negative effect of liquidity on bond ratings. This means that companies with high liquidity can have a low bond rating or vice versa companies with low liquidity can have a higher bond rating. The results of this study are in accordance with that presented by Ross \& Westerfield (2012), where bond ratings can change according to the ability or financial strength of a company that increases or decreases. According to Choudhry et al. (2009), bond ratings also often reflect the financial health of a company and the company's management, this means that liquidity can affect the 
good or bad rating obtained by the company. In addition, Brigham \& Houston (2016) also added that liquidity is part of the financial ratio factors that can affect bond ratings. The results of the study that have a significant negative effect of the liquidity on bond ratings is opposite to the results of Mardiyati et al. (2015) research which states that liquidity has a positive but not too significant effect on bond ratings and also research conducted by Partiningsih (2016), Hamid et al. (2019) which shows that liquidity has a significant positive effect on bond ratings.

The effect of maturity on bond ratings shows $p$ value of 0.0487 and the path coefficient of 0.0590 . Because the $p$ value is less than 0.05 and the path coefficient is 0.0590 , there is a positive effect of maturity on the bond rating. This shows that corporate bonds with high maturity will give a high rating, and vice versa if the maturity is low, the rating of the bond can be low. This result is the same as what was conveyed by Brigham \& Houston (2016) where, the bond ratings is determined based on various factors, namely quantitative factors and qualitative factors. Quantitative factors can be in the form of financial ratios, while qualitative factors can be in the form of bond contract provisions such as coupon rates, maturity etc. The results of this study also show the same results as the results of previous studies conducted by Veronica (2015) and Laeli \& Faizah (2019) which stated that maturity has a significant effect on bond ratings.

The effect of corporate governance on bond yields shows $p$ value of 0.6741 and the path coefficient of -0.0107 . Because the $p$ value exceeds 0.05 , there is no influence between corporate governance on bond yields. These results indicate that corporate governance does not affect the size of the bond yield of a company. Even though corporate governance is good, it does not mean that the yield provided by the company will be high as well. The determination of the size of the yield can be adjusted by the company with various considerations. The results of this study are not in line with the results of previous studies, where the results of previous studies stated that there was an influence of corporate governance on bond yields.

The effect of liquidity on bond yields shows $p$ value of 0.0699 and the path coefficient of -0.0730 . Because the $p$ value exceeds 0.05 , there is no effect of liquidity on bond yields. This means that company's liquidity will not affect bond yields. This result is not in accordance with that presented by Ross \& Westerfield (2012), where companies with low liquidity tend to choose to provide higher yields. Brigham \& Ehrhardt (2017), states that investors in investing in bonds want bond yields from companies that have good liquidity, this means investors will choose bonds with liquidity as one of the criteria in addition to the how much of the yield they want. The results of this study are the same as the results of previous studies conducted by Simu (2017), Susanti \& Permana (2017), Hamid et al. (2019), Putri et al. (2020), which states that bonds yield is not affected by liquidity.

The effect of maturity on bond yields shows a very small $p$ value, which is less than 0.05 and the path coefficient of 0.1744 . Because the $p$ value is smaller than 0.05 and the path coefficient is 0.1744 , there is a significant positive effect of maturity on bond yields. This means that bonds with long maturities will provide high yields as well, and vice versa, bonds with short maturities will provide lower yields. The results of this study are similar to those presented by Baker \& Filbeck (2013), where bonds with longer maturities are usually used to obtain higher yields and may be sold before maturity to meet liquidity needs. The results of this study also show the same results as previous studies conducted by Aisah \& Haryanto (2012), Che-Yahya et al. (2016), Putri et al. (2020) which says that maturity has an influence on bond yields. Simu (2017) also adds that the effect of maturity on yield is a positive influence.

The effect of bond ratings on bond yields shows a very small $p$ value, which is less than 0.05 and the path coefficient of -0.4381 . Because the $p$ value is smaller than 0.05 and the path coefficient is -0.4381 , there is a significant negative effect of bond rating on bond yields. Bonds with low ratings will provide high yields, and vice versa, bonds with high ratings will provide lower yields. The results of this study are in accordance with those presented by Choudhry et al. (2009), Drake \& Fabozzi (2010), Ross \& Westerfield (2012), Brigham Houston (2016), where the lower the bond rating, the higher the bond yield. These types of 
bonds are commonly referred to as high-yield bonds or junk bonds. The results of this study are the same as the results of previous studies conducted by Surya \& Nasher (2011), Hendaryadi et al. (2012), Simu (2017), Susanti \& Permana (2017), Weniasti \& Marsoem (2019), Putri et al. (2020) which states that there is an opposite relationship between bond ratings and bond yields.

Table 3 - Direct Effect Result

\begin{tabular}{|l|l|l|l|}
\hline $\mathrm{n} / \mathrm{n}$ & maturity & liquidity & corporate governance \\
\hline rating & 0.1119 & -0.2839 & 0.3773 \\
\hline yield & 0.4947 & -0.1180 & -0.0285 \\
\hline
\end{tabular}

Source: Result of output from SEM AMOS (2020).

Table 4 - Indirect Effect Result

\begin{tabular}{|l|l|l|l|}
\hline $\mathrm{n} / \mathrm{n}$ & maturity & liquidity & corporate governance \\
\hline rating & 0.0000 & 0.0000 & 0.0000 \\
\hline yield & -0.0734 & 0.1862 & -0.2475 \\
\hline
\end{tabular}

Source: Result of output from SEM AMOS (2020).

Table 5 - Total Effect Result

\begin{tabular}{|l|l|l|l|}
\hline $\mathrm{n} / \mathrm{n}$ & maturity & liquidity & corporate governance \\
\hline rating & 0.1119 & -0.2839 & 0.3773 \\
\hline yield & 0.4214 & 0.0682 & -0.2760 \\
\hline
\end{tabular}

Source: Result of output from SEM AMOS (2020).

Based on Table 3 and Table 4, it can be seen that the direct effect of corporate governance on yield is -0.0285 and the indirect effect of corporate governance on yield with bond rating as an mediating variable is -0.2475 so the total effect of corporate governance on bonds yield with bond ratings as mediating variable is -0.2760 . There is no influence of corporate governance on bonds yield, the effect of corporate governance on bond ratings is positive and the effect of bond ratings on yields is significant negative. These results indicate that the bond ratings in this study are fully mediating the effect of corporate governance on bond yields.

Based on Table 3 and Table 4, the direct effect of liquidity on bonds yield is -0.1180 and the indirect effect of liquidity on bond yield with bond ratings as a mediating variable is 0.1862 so that the total effect of liquidity on bonds yield with bond ratings as a mediating variable is $\mathbf{0 . 0 6 8 2}$. There is no effect of liquidity on bonds yield, the effect of liquidity on bond ratings is significant negative and bond ratings effect on bonds yield is significant negative. These results indicate that the bond ratings in this study are fully mediating the effect of liquidity on bond yields.

Based on Table 3 and Table 4 the direct effect of maturity on bonds yield is 0.4947 and the indirect effect of maturity on bonds yield with bond ratings as an mediating variable is 0.0734 so that the total effect of maturity on bonds yield with bonds rating as an mediating variable is 0.4214 . The effect of maturity on bonds yield is significant positive, the effect of maturity on bond rating is significant positive and the effect of bond ratings on bonds yield is significant negative. These results indicate that the bond ratings in this study are partially mediated the effect of maturity on bond yields.

\section{CONCLUSION}

Corporate governance has a significant positive effect on bond ratings so that the size of the board size can affect bond ratings. That mean the company with larger board size got more chance to get higher bond rating. Based on the results of the analysis, liquidity has a significant negative effect on bond ratings, so there is opposite effect between liquidity and 
bond ratings. Companies with high liquidity tend to have lower bond rating and companies with low liquidity tend to have higher bond rating. Maturity has a positive effect on bond ratings, so the length of maturity can affect the rating of bonds. There is unidirectional effect from maturity on bond ratings, which mean, the longer the maturity the higher the bond rating. There is no effect from corporate governance and liquidity on bond yields, so the size of board size and companies liquidity does not affect the bond yield that companies offer. Maturity has a significant positive effect on bond yields, so the length of maturity can affect the bond yield. The effect is unidirectional, that is mean the longer the maturity the greater the bond yields. Bond ratings have a significant negative effect on bond yields, so there is opposite effect between bond ratings on bonds yield. The higher bond ratings means the lower bonds yield that companies offer and the lower bond ratings they have the higher bonds yield the companies can offer. Bond ratings can mediate the influence of corporate governance, liquidity and maturity on bond yields.

\section{REFERENCES}

1. Altin, M., Kizildag, M., \& Ozdemir, O. (2016). Corporate governance, ownership structure, and credit ratings of hospitality firms. Journal of Hospitality Financial Management, 24(1), 5-19. https://doi.org/10.1080/10913211.2016.1166022.

2. Ashbaugh-Skaife, H., Collins, D. W., \& LaFond, R. (2006). The effects of corporate governance on firms' credit ratings. Journal of Accounting and Economics, 42(1-2), 203243. https://doi.org/10.1016/j.jacceco.2006.02.003.

3. Baker, H. K., \& Filbeck, G. (2013). Portfolio Theory and Management. In Portfolio Theory and Management. https://doi.org/10.1093/acprof:oso/9780199829699.003.0001.

4. Bhojraj, S., \& Sengupta, P. (2003). Effect of Corporate Governance on Bond Ratings and Yields: The Role of Institutional Investors and Outside Directors. Journal of Business, 76(3), 455-475. https://doi.org/10.1086/344114.

5. Blesia, J., \& Pramudika, D. (2016). Key Aspects of the Bond Ratings in Indonesia. Asian Journal of Economics, Business and Accounting, 1(3), 1-14. https://doi.org/10.9734/ajeba/2016/30244.

6. Bradley, M., Dallas, G. S., Snyderwine, E., \& Chen, D. (2011). The Effects of Corporate Governance Attributes on Credit Ratings and Bond Yields. SSRN Electronic Journal, 135. https://doi.org/10.2139/ssrn.1327070.

7. Brigham E. F. and J. F. Houston. 2016. Fundamentals of Financial Management, Concise Edition. South-Western College Pub.

8. Brigham, E., \& Ehrhardt, M. (2017). Financial Management - Theory and Practice, 15e. In Cengage Learning.

9. Che-Yahya, N., Abdul-Rahim, R., \& Mohd-Rashid, R. (2016). Determinants of corporate bond yield: The case of Malaysian bond market. International Journal of Business and Society, 17(2), 245-258. https://doi.org/10.33736/ijbs.523.2016.

10. Choudhry, M., Joannas, D., Landuyt, G., Pereira, R., \& Pienaar, R. (2009). Capital market instruments: Analysis and valuation. Capital Market Instruments: Analysis and Valuation, 1-546. https://doi.org/10.1057/9780230279384.

11. Chung, K. H., Wang, J., \& Wu, C. (2019). Volatility and the cross-section of corporate bond returns R. Journal of Financial Economics, 133(2), 397-417. https://doi.org/10.1016/j.jfineco.2019.02.002.

12. de Souza Murcia, F. C., Murcia, F. D. R., Rover, S., \& Borba, J. A. (2014). The determinants of credit rating: Brazilian evidence. BAR - Brazilian Administration Review, 11(2), 188-209. https://doi.org/10.1590/S1807-7692201400020005.

13. Dewi, M. S., \& Utami, E. M. (2020). The influence of profitability and liquidity to bond rating and the impact on the bond yield. International Journal of Research in Business \& Social Science, 9(4), 215-219.

14. Drake P. P. and F. J. Fabozzi. 2010. The Basics of Finance: An Introduction to Financial Markets, Business Finance, and Portfolio Management (Frank J. Fabozzi Series). Wiley. 
15. Elhaj, M. A. A., Muhamed, N. A., \& Ramli, N. M. (2015). The Influence of Corporate Governance, Financial Ratios, and Sukuk Structure on Sukuk Rating. Procedia Economics and Finance, 31(McMillen 2007), 62-74. https://doi.org/10.1016/s22125671(15)01132-6.

16. Hamid, A. A., Siagian, A., Razak, A., \& Endri, E. (2019). Determinants of Bond Rating and its Implications to Corporate Bond Yield. International Journal of Engineering and Advanced Technology, 9(2), 195-200. https://doi.org/10.35940/ijeat.b3358.129219

17. Hamida, L., Islam, U., \& Agung, S. (2017). Terhadap Yield Sukuk Dengan Peringkat. 7186.

18. Hendaryadi, Yusniar, M. W., \& Hadi, A. (2012). Pengaruh tingkat suku bunga, bond rating, ukuran perusahaan, debt to equity ratio (der) terhadap yield to maturity obligasi korporasi di bei periode tahun 2010-2012. Jurnal Wawasan Manajemen, Vol., 6(3), 295-309.

19. Ikhsan, A., Yahya, M. N., \& Saidaturrahmi. (2012). Peringkat Obligasi and Faktor yang Mempengaruhinya. PEKBIS ( Jurnal Pendidikan Ekonomi and Bisnis ), 4(2), 115-123. https://ejournal.unri.ac.id/index.php/JPEB/article/view/435.

20. Indonesia Stock Exchange. (idx.co.id, diakses Januari 2020).

21. Isnurhadi, \& Yanti, D. (2009). The effect of good corporate governance practices and bond rating on bond yield to maturity. Jurnal Akuntansi and Keuangan, 12(1), 1513-1543.

22. Kim, D. Y., \& Kim, J. (2014). Effects of corporate social responsibility and governance on its credit ratings. Scientific World Journal, 2014. https://doi.org/10.1155/2014/305452.

23. Laeli, Y., \& Faizah, N. (2019). Pengaruh Laverage Maturity and Size Perusahaan Terhadap Yield Obligasi Dengan Peringkat Obligasi Sebagai Variabel Intervening. 2(1), 43-54.

24. Leli Kurnia Sari \& Henny Murtini. (2015). Pengaruh Corporate Governance Terhadap. Accounting Analysis Journal 4 (1) (2015), 4(1), 1-13.

25. Mardiyati, U., Utami, S. G. N., \& Ahmad, G. N. (2015). The Effect Of Profitability, Liquidity, Leverage And Firm Size Toward Bond Rating On Non Financial Institution Listed In Indonesia Stock Exchange Period 2010-2014. Jurnal Riset Manajemen Sains Indonesia (JRMSI) | Vol 6, No. 2, 2015, 6(2), 579-598.

26. Otoritas Jasa Keuangan. (ojk.go.id, diakses Januari 2020).

27. Partiningsih, D. N. (2016). Pengaruh Faktor Keuangan, Non Keuangan Terhadap Peringkat Obligasi : Manajemen Laba Sebagai Intervening. 5, 1-25.

28. Putri, R. M., Siregar, H., \& Andati, T. (2020). Analisis pengaruh kupon, maturity, likuiditas, and rating obligasi terhadap yield obligasi perbankan. Jurnal IImiah Bisnis and Ekonomi Asia, 14(1), 1-13. https://doi.org/10.32812/jibeka.v14i1.125.

29. Rizal, S., \& Sutanti, W. (2015). The Effect Of Growth, Profitability And Liquidity To Bond Rating Of The Banking Firms Listed On The Indonesian Stock Exchange (Period 20092013). IMCoSS.

30. Ross S., R. Westerfield, and J. Jaffe. 2012. Corporate Finance. McGraw-Hill/Irwin, New York, AS.

31. Sahabuddin, Z. A., \& Hadianto, B. (2020). The impact of the supervisory board on bond ratings of non-financial companies. Investment Management and Financial Innovations, Volume 17, Issue 1, 2020, 17(1), 15-23.

32. Sari, R. K., Nurlaela, S., \& Titisari, K. H. (2018). The Effect of Liquidity Ratio, Profitability Ratio, Company Size, and Leverage on Bond Rating in Construction and Real Estate Company. 2018.

33. Setyaningrum, D. (2005). Pengaruh Mekanisme Corporate Governance Terhadap Peringkat Surat Utang Perusahaan Di Indonesia. Jurnal Akuntansi and Keuangan Indonesia, 2(2), 73-102. https://doi.org/10.21002/jaki.2005.11.

34. Simu, N. (2017). Determinants of indonesian corporate bond yield. Business and Economic Horizons, 13(5), 619-629. https://doi.org/10.15208/beh.2017.42.

35. Surya, B., \& Nasher, T. (2011). Analisis Pengaruh Tingkat Suku Bunga SBI, Exchange Rate, Ukuran Perusahaan, Debt to Equity Ratio and Bond Terhadap Yield Obligasi Korporasi Di Indonesia. Journal of Technology Management, 10(2). 
36. Susanti, N., \& Permana, M. R. (2017). Pengaruh Peringkat, Likuiditas, Kupon and Maturitas Terhadap Yield Obligasi Pada Bursa Efek Indonesia (Bei) Periode 2013-2014. Jurnal Muara Ilmu Ekonomi and Bisnis, 1(1), 1. https://doi.org/10.24912/jmieb.v1i1.400

37. Tandelilin, Eduardus. 2010. Portofolio and Investasi Teori and Aplikasi. Edisi pertama. Yogyakarta: Kanisius.

38. Tarigan, C. K., \& Fitriany, F. (2018). Impact of Corporate Governance on Credit Rating. 55(lac 2017), 248-253. https://doi.org/10.2991/iac-17.2018.44.

39. Utomo, A. D., Anwar, K., Keuangan, M., \& Ekonomi, F. (2016). Pengaruh Good Corporate Governance Terhadap The Effect Of Good Corporate Governance On Bond Rating In Manufacturing Companies Listed In Indonesia Stock Exchange. 02(02), 1-11.

40. Veronica, A. (2015). Faktor-Faktor Yang Mempengaruhi Peringkat Obligasi Pada Perusahaan Manufaktur. Jurnal Manajemen and Bisnis Sriwijaya, 13(2), 271-282. https://doi.org/10.29259/jmbs.v13i2.3373.

41. Weniasti, A., \& Marsoem, B. S. (2019). The Effect of Bonds Rating, Profitability, Leverage, and Firm Size on Yield to Maturity Corporate Bonds. International Journal of Innovative Science and Research Technology, 4(8), 286-295. 